\title{
A REVIEW OF VEHICLES SPEED ON SCHOOL SAFETY ZONE AREAS IN PEKANBARU CITY
}

\author{
Lusi Dwi Putri, Fitridawati Soehardi and Alfian Saleh \\ University of Lancang Kuning, Pekanbaru, Indonesia, 28265 \\ Tel / Fax: + 6276152324 \\ E-mail: lusidwiputri @ unilak.ac.id, fitridawati@unilak.ac.id, alfian.saleh@unilak.ac.id
}

\begin{abstract}
School Safety Zone is a location or region on particular roads that are time-based speed zone to set the speed of the vehicle in the school environment. The maximum speed limit permits entering a School Safety Zone, especially in Pekanbaru City is $25 \mathrm{~km} / \mathrm{h}$ and an outline of the speed limit permit vehicles that pass through the School Safety Zone in Indonesia is generally $20-30 \mathrm{~km} / \mathrm{h}$. However, the vehicles speeds that pass School Safety Zone are higher than permit speeds. To ensure the level of vehicle offense across the territory of the School Safety Zone so it is necessary a primary data which is taken randomly based on field survey for 3 days at schools that has that facility ie SDN 3 Jalan Kesehatan Pekanbaru City, SDN 68 Jalan Balam Ujung Kota Pekanbaru and SDN 143 Jalan Taskurun Kota Pekanbaru. Furthermore, the data were taken in good condition that is at $6: 30$ to 7:30 am and at 12:00 to 13:00 pm. In addition, the data obtained is mileage and travel time of the vehicle. Both of these data can generate good speed value that passes through the area of

School Safety Zone. Based on the research findings, the vehicle speed passing through the area of School Safety Zone is incompatible with speed permit at $35 \mathrm{~km} / \mathrm{h}$. This indicates that the vehicle passes School Safety Zone not following the rules of the maximum limit area and can be potentially harmful to elementary school students.
\end{abstract}

Keywords: Mileage, Speed, School Safety Zone, Travel Time

\section{Introduction}

Many schools in big cities are located on the edge of the highway, where many vehicles are driving at high speed. One of the busiest traffic roads is the West Cross Road. West Cross Road is a road that connects Pekanbaru City with Kampar regency, even some roads in Pekanbaru City called 'Trajectory' like Jalan HR Soebrantas because of the many trucks that pass.

The conditions mentioned above will be very dangerous for school students when going across the street. School students, especially elementary school students (elementary school) are still vulnerable in traffic such as when crossing the road. According to kalantas data from Polresta Pekanbaru City, Pelalawan Regency and Kampar regency of 2016 is not very significant from the previous year and some have decreased, but the risk we need to anticipate before the victims occurred considering the object of this study is the elementary and junior high school in fact inhabited by children, children who do not understand the ethics of traffic, especially during school hours and when returning from school. Not all schools have ZoSS facilities even though the visual conditions should be eligible for ZoSS. Even for some schools that have facilities ZoSS current conditions such as unkempt for example street color of the school (usually red) is no longer clear color.
The implementation of Zoss is one form of traffic management in order to fulfill the sense of security in crossing the road for pedestrians. According to the Department of Transportation, the Director General of Land Transport (2006) "School Safe Zone (ZoSS)" is a location on a particular road segment which is a time-based velocity zone to regulate the pace in the school environment ". This is also explained by the Ministry of Transportation of the Directorate General of Land Transport (2014) "Zoss is controlling traffic activities through speed regulation by placing markers and signs on roads in schools that aim to prevent accidents in order to ensure safety in schools".

\section{Literature Review}

The School Safe Zone (ZoSS) is a zone for certain road segments in a school environment with a time-based speed. Through traffic engineering, this zone is equipped with supporting facilities that can adjust the speed of the vehicle. At Zona Saving School (ZoSS) expected safe, convenient, easy and economical traffic. The ZoSS facility is installed at schools located on arterial roads and collectors. The installation of ZoSS on a national road which is the primary arterial or collector 1 (KP 1) road is designated specifically for schools that have been built on the national side of the road and there is no alternative to 
school roads. At ZoSS the required road safety facilities are zebra cross, warning signs, a guidance of crossing locations and many children's signs.

To limit the permitted speed at the ZoSS location of 20 $\mathrm{km}$.jam, $25 \mathrm{~km} / \mathrm{h}$, and $30 \mathrm{~km} / \mathrm{h}$, the determination is done by the related survey:

a. The behavior of road users, including pedestrian behavior while crossing the street and pedestrian behavior down the street.

b. Traffic conditions include: Inventory of roads, traffic volume, pedestrians, and vehicle speed

The requirement of ZoSS is the unavailability of pedestrian bridges, schools that have direct access to roads with students over 50 students. According to the Ministry of Transportation of the Directorate General of Land Transport (2014), based on the school's location criteria, ZoSS can be classified by single and plural ZoSS. Single and plural ZoSS consists of 4 types of road segments ie $2 / 2$ UD road types (two lanes, two undivided directions), 4/2 UD road type (four lanes, two undivided lanes), 2/2 D type road ( two lanes, two divided directions), 4/2 D type road (four lanes, two divided paths).

\section{a. Single Zoss}

It is a ZoSS assigned to 1 school in a location. Single ZoSS form and size consists of 4 types of road segments ie road type $2 / 2 \mathrm{UD}, 4 / 2 \mathrm{UD}, 2 / 2 \mathrm{D}$, and 4/2 D.

b. ZoSS plural

It is a ZoSS defined for 2 schools or more that are located adjacent to the sailing. ZoSS plural fitted with the provisions crosswalk and outer distance ZoSS. Zebra cross is installed in every entrance/entrance to school and ZoSS outer distance is measured from the outermost schools. The distance between the access entrance to the school with other schools $\geq 50$ meters, if $<50$ meters, then the zebra crossing merged into one.

Facility of road equipment in ZoSS region consists of 3 parts:

a. Road markings

According to Warpani (2002: 95) " road markings are in the form of lines, images, darts, and the insignia on the road surface that serves to direct traffic flow and limit traffic areas of interest". The road marker contains command messages, warnings, directions and restrictions consisting of 3 colors:

1) The marka is white, stating that road users are obliged to follow orders or restrictions according to their form. The white marks consist of single intact white lines, single dashed white lines, double white lines, white lines and white dotted lines and white lines
2) The marka is yellow, stating that road users are not allowed to stop in the area

3) A red marka, a red road marker indicating a need or a special mark.

b. Traffic signs

Traffic signs are part of street equipment in the form of symbols, letters, numbers, sentences, and/or combinations that serve a warning, prohibition, command or instructions for road users (Kemenhub, 2014). Type of signs consists of 4 parts, namely:

1) Warning signs indicate the possibility of a road hazard to be traversed. Warning shaped rhombus, colored yellow base with black insignia or writing

2) Prohibition signs that form the arrangement contain the prohibitions that can not be done by road users. A circular band with white base color and black or red writing or writing. Signs the special ban in the form of an equilateral octagonal.

3) Guidance signs that provide guidance on majors, road conditions, situation, the next city, the existence of facilities, and others. Signed instructions are rectangular

4) Command signs are shaped clear and clear settings without any other interpretation that must be implemented by road users. Command signs are round, blue base color with white or red insignia or writing for oblique lines at the end of the command.

c. Road user safety device

Road user safety device that is in the form of ribbon band. Ribbon tape is an additional fixture on the road that serves to make the driver more alert. Rotting bands may be a road marker or other material mounted across a traffic lane with a maximum thickness of $4 \mathrm{~cm}$. while the homecoming tape for the School Safe Zone is installed 50 meters from the outer ZoSS line. At very low traffic volume or kissing with a very good road, then the rider can run his vehicle in accordance with his wishes within the perceived safety, without feeling influenced by the existence of other vehicles. In this condition, it can be said that the traffic on the road is said to free flow, and the speed at this condition is called the velocity of free flow. However, if the road conditions are solid, there are many pedestrian factors crossing the road, affecting the road, causing conflict.Things that affect the road is called the side barriers that is a side activity that often leads to conflict and greatly affects the traffic flow. Side barriers such as; pedestrians crossing the road, pedestrians walking along the side of the road, parking vehicles 
or stopping by the side of the road, lambda vehicles, such as becak, bendi, bikes, and merchants selling on the sidewalk

\section{Methodology}

The type of this research is descriptive research to describe in fact the speed at the location using Zoss and location not using ZoSS. The data needed are primary and secondary data. Primary data is data obtained directly in the field is the time (seconds) and distance $(\mathrm{km} / \mathrm{h})$ at the location of SDN 3 Jl. Balam Ujung, SDN 68 Jl. $\begin{array}{lllll}\text { Kesehatan, SDN } & 143 \quad \text { Jl.Tasykurun, } & \text { SDN } & 18\end{array}$ Jl. Kulim, SDN 55 Jl.Kayangan and SDN 163 Jl. HR. Subrantas Pekanbaru. Time survey is sixty (60) minutes at the time of entry to and from school is at $6: 30$ to $7: 30 \mathrm{pm}$ and at 12:00 to $13: 30 \mathrm{pm}$ and observed on Monday, Tuesday and Wednesday. While the secondary SDN 68data obtained from related parties include Pekanbaru City Department of Education and the Department of Transportation in Pekanbaru, such as the type of road.

Speed can be measured as point velocity, travel speed, space velocity and velocity. (Oktaviani; 2014):

Speed formula in general:

$$
\mathrm{V}=\frac{d}{t}
$$

$$
\begin{aligned}
\mathrm{V} & =\text { speed }(\mathrm{km} / \mathrm{h}) \\
\mathrm{d} & =\text { mileage }(\mathrm{km}) \\
\mathrm{t} & =\text { travel time (hours) }
\end{aligned}
$$

Speed is known for 5 kinds namely:

a. Time mean speed (average speed time)

It is the average speed of all passing vehicles at a certain point in certain periods of time.

$$
\mathrm{Vt}=\frac{1}{n} \sum_{i=1}^{n} v i
$$

$\mathrm{Vt}=$ average speed of time $(\mathrm{km} / \mathrm{h})$

$\mathrm{n}$ = number of speed data observed

vi $=$ speed of each vehicle observed $(\mathrm{km} / \mathrm{h})$

b. Space mean speed (average speed space)

It is the average speed of all vehicles that are in a road segment for a certain period of time. Space mean speed is calculated using the following formula. (Oktaviani; 2014):

$$
\mathrm{Vs}=\frac{1}{\frac{1}{n} \sum_{i=1}^{n} \frac{1}{V i}}
$$

$$
\begin{aligned}
& \mathrm{Vs}=\text { average space velocity }(\mathrm{km} / \mathrm{h}) \\
& \mathrm{n} \quad=\text { number of speed data observed } \\
& \mathrm{vi}=\text { speed of each vehicle observed }(\mathrm{km} / \mathrm{h})
\end{aligned}
$$

c. Spot Speed (instantaneous velocity)

Speed is shown in the speedometer.

d. Running speed (moving speed)

It is the average speed of a vehicle during a move:

$$
\text { Running Speed }=\frac{\text { Mileage }}{\text { Running Time }}
$$

e. Journey speed (traveling speed)

It is the average speed of the journey calculated from the distance divided by the travel time.

$$
\text { Journey Speed }=\frac{\text { Jarak tempuh }}{\text { Journey } \text { Time }}
$$

\begin{tabular}{|c|c|c|c|c|c|}
\hline \multicolumn{6}{|c|}{ Average vehicle speed at the site using Zoss } \\
\hline Day & Time & School & $\mathrm{n}$ & $\Sigma \mathrm{Vi}$ & $\mathrm{Vt}$ \\
\hline \multirow{2}{*}{$\begin{array}{l}\text { Monday } \\
\text { May } 2017\end{array}$} & $06.30-07.30$ & \multirow{6}{*}{$\begin{array}{l}\text { SDN } 3 \\
\text { Jl.Balam } \\
\text { Ujung } \\
\text { Pekanbaru }\end{array}$} & 118 & 4233 & 36 \\
\hline & $12: 00$ to $13: 00$ & & 150 & 5534 & 37 \\
\hline \multirow{2}{*}{$\begin{array}{l}\text { Tuesday } \\
\text { May } 2017 \\
\end{array}$} & $06.30-07.30$ & & 167 & 6867 & 41 \\
\hline & $12: 00$ to $13: 00$ & & 187 & 7344 & 39 \\
\hline \multirow{2}{*}{$\begin{array}{l}\text { Wednesday } \\
\text { May } 2017\end{array}$} & $06.30-07.30$ & & 198 & 8977 & 45 \\
\hline & $12: 00$ to $13: 00$ & & 204 & 9345 & 38 \\
\hline \multirow{2}{*}{$\begin{array}{l}\text { Monday } \\
\text { M ei } 2017\end{array}$} & $06.30-07.30$ & \multirow{6}{*}{$\begin{array}{l}\text { SDN } 68 \\
\text { Jl.Kesehat } \\
\text { an } \\
\text { Pekanbaru }\end{array}$} & 377 & 12300 & 33 \\
\hline & $12: 00$ to $13: 00$ & & 392 & 13507 & 34 \\
\hline \multirow{2}{*}{$\begin{array}{l}\text { Tuesday } \\
\text { May } 2017\end{array}$} & $06.30-07.30$ & & 406 & 14355 & 35 \\
\hline & $12: 00$ to $13: 00$ & & 418 & 15663 & 37 \\
\hline \multirow{2}{*}{$\begin{array}{l}\text { Wednesday } \\
\text { May } 2017\end{array}$} & $06.30-07.30$ & & 423 & 15884 & 38 \\
\hline & $12: 00$ to $13: 00$ & & 438 & 15446 & 35 \\
\hline \multirow{2}{*}{$\begin{array}{l}\text { Monday } \\
\text { May } 2017 \\
\end{array}$} & $06.30-07.30$ & \multirow{6}{*}{$\begin{array}{l}\text { SDN } 143 \\
\text { Jl.Taskuru } \\
\mathrm{n} \\
\text { Pekanbaru }\end{array}$} & 110 & 3345 & 30 \\
\hline & $12: 00$ to $13: 00$ & & 121 & 3598 & 30 \\
\hline \multirow{2}{*}{$\begin{array}{l}\text { Tuesday } \\
\text { May } 2017 \\
\end{array}$} & $06.30-07.30$ & & 147 & 4325 & 29 \\
\hline & $12: 00$ to $13: 00$ & & 168 & 4453 & 27 \\
\hline \multirow{2}{*}{$\begin{array}{l}\text { Wednesday } \\
\text { May } 2017\end{array}$} & $06.30-07.30$ & & 179 & 5433 & 30 \\
\hline & $12: 00$ to $13: 00$ & & 197 & 5576 & 28 \\
\hline \multicolumn{5}{|l|}{ Average } & 35 \\
\hline
\end{tabular}

\section{Results and Discussion}

The results of the study in the city of Pekanbaru, the average speed of motorists on schools that have facilities ZoSS of the survey results and the calculation speed of vehicles to SDN 3 Ujung Jalan Balam, SDN 68 and SDN 143 Health Jl Jl Tasykurun can be seen in Table 1.

Table 1. Speed of vehicle in location using ZoSS in Pekanbaru City 
With:

$\mathrm{n} \quad=$ Lots of speed data

$\Sigma \mathrm{Vi}=$ Total speed of vehicle $(\mathrm{km} / \mathrm{h})$

$\mathrm{Vt}=$ Average speed $(\mathrm{km} / \mathrm{h})$

From the data analysis only 143 Jl.Taskurun approaching SDN standard average speed of vehicles is permitted, namely $29 \mathrm{~km} \mathrm{/} \mathrm{h} \mathrm{but} \mathrm{still} \mathrm{exceeds} \mathrm{the} \mathrm{limit}$ diz Inkan, is caused by the location of the category of the population and has a bustling location beside the huge obstacles. Causes the rider to adhere to ZoSS area rules. While in two different locations, motorists do not comply with the permit speed rules when passing ZoSS area, for SDN 3 Jl Balam Ujung Pekanbaru average speed of riders that is $41 \mathrm{~km} / \mathrm{h}$ and SDN $68 \mathrm{Jl}$ Health Pekanbaru average speed of rider that is $35 \mathrm{~km} / \mathrm{h}$. This is due to the fairly large road width, the less dense currents, the lack of side barriers and the very lack of awareness of motorists in passing through ZoSS territory. However, if averaged from the three locations, the speed of vehicles passing through the ZoSS area still exceeds the allowed speed of $35 \mathrm{~km} / \mathrm{h}$.

The results of the study in the city of Pekanbaru, the average speed of motorists on schools that do not have the facilities ZoSS of the survey results and the calculation speed of vehicles to SDN 18 Jalan Kulim, SD N 163 Jl. HR Subrantas and SDN $55 \mathrm{Jl}$ Kayangan can be seen in Table 2.

Table 2. On-site vehicle speed does not use ZoSS in Pekanbaru City

\begin{tabular}{|c|c|c|c|c|c|}
\hline \multicolumn{6}{|c|}{ Average vehicle speed at the site not use Zoss } \\
\hline Day & Time & School & $\mathrm{n}$ & $\Sigma \mathrm{Vi}$ & $\mathrm{Vt}$ \\
\hline \multirow{2}{*}{$\begin{array}{l}\text { Monday } \\
\text { May } 2017\end{array}$} & $06.30-07.30$ & \multirow{6}{*}{$\begin{array}{l}\text { SDN } 18 \\
\text { Jl. Kulim } \\
\text { Pekanbaru }\end{array}$} & 121 & 4188 & 35 \\
\hline & $12: 00$ to $13: 00$ & & 135 & 4221 & 31 \\
\hline \multirow{2}{*}{$\begin{array}{l}\text { Tuesday } \\
\text { May } 2017\end{array}$} & $06.30-07.30$ & & 153 & 4323 & 28 \\
\hline & $12: 00$ to $13: 00$ & & 187 & 7134 & 38 \\
\hline \multirow{2}{*}{$\begin{array}{l}\text { Wednesday } \\
\text { May } 2017\end{array}$} & $06.30-07.30$ & & 203 & 7554 & 37 \\
\hline & $12: 00$ to $13: 00$ & & 245 & 8654 & 35 \\
\hline \multirow{2}{*}{$\begin{array}{l}\text { Monday } \\
\text { M ei } 2017\end{array}$} & $06.30-07.30$ & \multirow{6}{*}{$\begin{array}{l}\text { SDN } 163 \\
\text { Jl.HR.Sub } \\
\text { rantas } \\
\text { Pekanbaru }\end{array}$} & 412 & 15663 & 38 \\
\hline & $12: 00$ to $13: 00$ & & 433 & 16773 & 39 \\
\hline \multirow{2}{*}{$\begin{array}{l}\text { Tuesday } \\
\text { May } 2017 \\
\end{array}$} & $06.30-07.30$ & & 389 & 16773 & 43 \\
\hline & $12: 00$ to $13: 00$ & & 418 & 17445 & 42 \\
\hline \multirow{2}{*}{$\begin{array}{l}\text { Wednesday } \\
\text { May } 2017\end{array}$} & $06.30-07.30$ & & 423 & 16889 & 40 \\
\hline & $12: 00$ to $13: 00$ & & 438 & 16773 & 38 \\
\hline \multirow{2}{*}{$\begin{array}{l}\text { Monday } \\
\text { May } 2017\end{array}$} & $06.30-07.30$ & \multirow{6}{*}{$\begin{array}{l}\text { SDN } 55 \\
\text { Jl.Kayang } \\
\text { an } \\
\text { Pekanbaru }\end{array}$} & 122 & 3877 & 32 \\
\hline & $12: 00$ to $13: 00$ & & 188 & 5885 & 31 \\
\hline \multirow{2}{*}{$\begin{array}{l}\text { Tuesday } \\
\text { May } 2017\end{array}$} & $06.30-07.30$ & & 204 & 6234 & 31 \\
\hline & $12: 00$ to $13: 00$ & & 226 & 8775 & 39 \\
\hline \multirow{2}{*}{$\begin{array}{l}\text { Wednesday } \\
\text { May } 2017 \\
\end{array}$} & $06.30-07.30$ & & 244 & 9877 & 40 \\
\hline & $12: 00$ to $13: 00$ & & 201 & 8775 & 44 \\
\hline \multicolumn{5}{|l|}{ Average } & 33 \\
\hline
\end{tabular}

With:

$$
\begin{aligned}
& \mathrm{n} \quad=\text { Lots of speed data } \\
& \Sigma \mathrm{Vi}=\text { Total speed of vehicle }(\mathrm{km} / \mathrm{h}) \\
& \mathrm{Vt}=\text { Average speed }(\mathrm{km} / \mathrm{h})
\end{aligned}
$$

From the data analysis in Pekanbaru City average speed of motorists on schools that do not have the facilities ZoSS everything past the allowed limit is $28 \mathrm{~km} / \mathrm{h}, 34 \mathrm{~km}$ / h, and $36 \mathrm{~km} / \mathrm{h}$. For SDN $18 \mathrm{Jl}$ Kulim Pekanbaru the average speed of the rider is $34 \mathrm{~km} \mathrm{/} \mathrm{h,} \mathrm{SDN} 163$ J1. HR.Subrantas Pekanbaru average speed of riders is 28 $\mathrm{km} / \mathrm{h}$ and SDN 55 Jl.Kayangan Pekanbaru average speed of the rider is $36 \mathrm{~km} /$ hour. For SDN $18 \mathrm{Jl}$ Kulim Pekanbaru and SDN $55 \mathrm{Jl}$. Kayangan Pekanbaru is caused by a large enough road width, less dense flow, and very lack of awareness of motorists in passing the area without ZoSS. For SDN 163 Jl. HR.Subrantas Pekanbaru However, if averaged from the three locations, the speed of vehicles passing through areas that do not have ZoSS facilities exceed the permitted speed of $33 \mathrm{~km} / \mathrm{h}$.

\section{Conclusions}

From the survey results that have been done, it can be seen that:

1. The average speed of riders passing ZoSS exceeds the permitted standard speed limit $(25 \mathrm{~km} / \mathrm{h}$ for inner city roads) of $35 \mathrm{~km} / \mathrm{h}$.

2. The average speed of riders passing through school areas that do not have ZoSS exceeds the standard allowable speed limit ( $25 \mathrm{~km} / \mathrm{h}$ for inner city roads) of $33 \mathrm{~km} / \mathrm{h}$

\section{References}

Data Riau.com, 2014, Jalan HR Soebrantas, Lintasan Maut di Pekanbaru, Aviable from : http://datariau.com/read-13-829-2014-10-24-jalanhr-soebrantas-lintasan-maut-di-pekanbaru.html, Accesed : 2016, April 13

Kurniati, T ., dkk, 2010, Evaluasi Penerapan Zona Selamat Sekolah di Kota Padang, Jurnal Rekayasa Sipil Volume. 6, No.2, pp. $7-10$

Oktaviani. (2014). Teknik Lalu Lintas, Padang: Teknik Sipil Fakultas Teknik Universitas Negeri Padang.

Peraturan Menteri Perhubungan Republik Indonesia Nomor PM 13 Tahun 2014 tentang Rambu Lalu Lintas

Peraturan Menteri Perhubungan Republik Indonesia Nomor PM 34 Tahun 2014 tentang Marka Jalan

Sari, N.M, 2015, "Tinjauan Kecepatan Kendaraan pada Wilayah Zona Selamat Sekolah (ZoSS) di Kota Padang", ProsidingAnnual Civil Engineering Seminar, ISBN :978-979-792-636-6, Universitas Riau, Pekanbaru

Sari, N.M, 2015, "Tinjauan Kecepatan Kendaraan pada Wilayah Zona Selamat Sekolah (ZoSS) di Kota Padang",

ejournal.unri.ac.id/ACES/article/download/2994/29 26, Accesed : 2016, february 07 
Tamin, O.Z, 2008, "Perencanaan, Pemodelan dan Rekayasa Transportasi”, Institut Teknologi Bandung

Wahyuni, Sri, 2012, "Analisis Efektifitas Zona Selamat Sekolah (ZoSS) di Sekolah Dasar Kota Pekanbaru”, http://repository.unri.ac.id/xmlui/bitstream/handle/1 23456789/2050/SRI\%20WAHYUNI\%20\%20(NIM $\% 200707131855)$.pdf?sequence $=1$, Accesed : 2016, April 03 